\title{
THE POLICY (IN)EFFICACY OF GOVERNMENT SPENDING IN A DEPENDENT ECONOMY ${ }^{1}$
}

\author{
Anthony J. Makin \\ Griffith University \\ Gold Coast, 4222 \\ Australia \\ t.makin@griffith.edu.au
}

\section{Introduction}

As a macroeconomic policy response to the Global Financial Crisis of 2008-09 many governments deployed fiscal stimulus in the form of public spending to stabilize national output and employment levels. Most notably, the Group of 20 (G20) implemented the largest internationally co-ordinated fiscal policy initiative the world has ever seen. Public spending was boosted and taxes were cut to deliver stimulus packages valued on average at 2 per cent of world GDP in 2009 and 1.6 per cent in 2010 (IMF 2010). This response reflected the textbook Keynesian idea that government spending can supplement depressed private spending and temporarily boost economic activity, a notion that has appealed to economists and governments since the Great Depression of the 1930s.

The flourishing literature on the effectiveness of fiscal policy of recent years has to date mostly examined the empirical dimension of deploying alternative fiscal instruments to stabilize national income and employment, with a particular focus on

\footnotetext{
${ }^{1}$ The author gratefully acknowledges the constructive comments of two anonymous referees.
} 
quantifying fiscal multipliers. See, for instance, Gali, Lopez-Salido and Valles (2007), Romer and Romer (2008), Tagkalakis (2008), Mountford and Uhlig (2009), Auerbach et al (2010), Cogan et al (2010), Kollman (2010), Ramey (2011), Woodford (2011), Davig and Leeper (2011), and Ravn et al (2012). In keeping with the Keynesian tradition, the bulk of this recent literature also abstracts from international economic influences, implicitly presuming the closed economy effects of fiscal stimulus predominate.

In contrast, the Mundell (1963) - Fleming (1962) model, a still popular framework for analyzing the effectiveness of fiscal and monetary policies in open economies, concludes that fiscal policy is ineffective as a means of stabilizing national income and employment if nominal exchange rates float. On the contrary, this paradigm also concludes fiscal policy is very effective if nominal exchange rates are fixed. Yet the Mundell-Fleming approach implicitly assumes all goods and services are internationally saleable, making no distinction between goods and services that are tradable and those that are non-tradable.

Another stream of the international macroeconomics literature based on this distinction follows the tradition of the so-called dependent economy model, originally proposed by Salter (1959) and Swan (1960). Previous models based on the two sector premise include Fischer and Frenkel (1972), Dornbusch (1974), Bruno (1976), Obstfeldt and Rogoff (1996), Asea and Mendoza (1994), Yano and Nugent (1999) Morshed and Turnovsky (2004) and Makin (2013). Numerous other variants focus explicitly on the international macroeconomic effects of fiscal policy. For instance, from a neo-classical intertemporal optimizing perspective Turnovsky and Sen (1995), 
Coto-Martinez and Dixon (2003), and Cardi and Restout (2012) employ the tradablenontradable dichotomy to examine the effects of expansionary budgetary policies, with the latter two papers assuming elastic labor supply to highlight the role of competition in product markets. From this perspective, an increase in public spending crowds out investment, gives rise to a current account deficit and expands GDP, assuming the tradables sector is more capital intensive than the non-tradables sector.

This paper provides a new framework for interpreting the effectiveness of fiscal policy in open economies. More particularly, it proposes a new fiscal transmission mechanism highlighting the short run effects of government spending on national income, the current account and the real exchange rate, defined as the relative price of non-tradables to tradables. In preview, by extending the dependent economy approach it shows that additional government spending on either tradables or nontradables widens the current account deficit, provided international capital mobility is high, and in the case of higher spending on non-tradables appreciates the real exchange rate.

Additionally, it reveals that in principle government spending has a zero or (minimally) ambiguous impact on national output and employment, regardless of whether the extra spending is on tradables or non-tradables. However, the size of any government spending multiplier ultimately depends on the elasticities of tradable and non-tradable output with respect to changes in the real exchange rate. Moreover, with a high degree of capital mobility whether the nominal exchange rate is floating or fixed has little bearing on these results, contrary to the lessons of the standard Mundell-Fleming model. It also shows that fiscal policy is ineffective when deemed 
unsustainable by foreign lenders and when the exchange rate is pegged under conditions of limited capital mobility.

The theoretical predictions of the paper can be compared with previous empirical findings on this issue, particularly those of numerous papers that have estimated open economy fiscal effects using VAR analysis. For instance, Corsetti and Muller (2006), Beetsma, Guiliordori and Klaasen (2008), Monacelli and Perotti (2010) and Cardi and Muller (2011) find that exogenous public spending increases have a positive effect on GDP and generate current account deficits. Moreover, also using VAR analysis, Born, Juessen and Muller (2013) show that, consistent with standard MundellFleming analysis, government spending multipliers tend to be larger when exchange rates are fixed, while Corsetti, Meier and Muller (2012) find that the response of the real exchange rate systematically varies with the exchange rate regime. Meanwhile Cortuk (2013) has highlighted the importance of the type of government spending, particularly public wage and non-wage consumption versus investment, when examining the variety of fiscal multipliers.

Methodologically, what distinguishes the following exposition from recent related work is that it develops a theoretical framework which is in the aggregative tradition, without recourse to microfoundations. This facilitates focus on the immediate international macroeconomic effects of a government spending shock on those macro variables of primary interest to policymakers. Based on standard accounting and behavioural relations linking the real and monetary sectors, it traces out the adjustment paths of the real exchange rate, the current account balance, national output (and employment). Optimising representative agents with rational 
expectations are not invoked on the grounds that this would introduce unnecessary complexity and tie results to whichever underlying utility function is somewhat arbitrarily chosen (Sarno and Taylor 2003).

The next section develops a simple two sector geometric framework for examining the short run impact of increased government spending in a small economy producing tradable and non-tradable output. Section 3 then analyses the international macroeconomic impact of increased government spending on tradable and nontradable goods and services under alternative capital mobility and exchange rate regime assumptions. Section 5 summarises the key findings, highlighting new results for policymakers.

\section{The Two Sector Model}

This section outlines the key relationships underpinning a straightforward two sector model, later used to examine the impact of government spending on the exchange rate, national output, employment and the current account balance. The economy produces and consumes two distinct classes of goods and services - tradables (actual and potentially traded goods and services), and non-tradables (including personal and public sector services, construction, utilities, local transport services, and goods produced under conditions where transport costs or tariffs ensure international exchange is prohibitive). The prices of non-tradables are set by domestic demand and supply factors, whereas the foreign currency prices of tradable goods and services are set in world markets, and converted to domestic values via the prevailing exchange rate. 
Expenditure and Output in the Tradable and Non-tradable Sectors

Consistent with the standard national accounting identity, gross domestic product, the total quantity of tradable and non-tradable goods and services made available for sale to resident and non-resident entities, can be expressed as

$$
Y=O_{T}+O_{N}=E_{T}+E_{N}+C A
$$

where $Y$ is real national output or national income, comprised of tradable output, $O_{T}$, and non-tradable output, $O_{N}$. Expenditure by resident entities on tradable and nontradable output is $E_{T}$ and $E_{N}$ respectively, and, abstracting from income paid abroad, $C A$ is the difference between domestic spending and national income, as highlighted originally by Alexander (1952). This contrasts with the conventional view that trade and current account imbalances primarily reflect the difference between foreign demand for exports and domestic demand for imports. If in deficit, the current account must be funded by capital inflow, or under pegged rates by a rundown in the central bank's foreign exchange reserves.

Domestic firms and households are price takers in world markets for tradables and the nominal exchange rate converts the foreign currency prices of tradables into domestic currency terms, such that

$$
P_{T}=e P_{T}^{*}
$$

where $P_{T}$ is an index of the price of tradables, $P_{T}^{*}$, is an index of the world price of tradables and $e$ is the nominal effective exchange rate, defined as the price of foreign currency. If world prices are assumed exogenous and stable, only changes in the nominal exchange rate alter the price level of tradables in local currency terms. 
On the other hand, the price of non-tradables, reflected in the index measure $P_{N}$, is set by domestic demand and supply conditions. The real exchange rate, $R$, is the ratio of the domestic currency price of non-tradables to tradables, a rise in which signifies a real appreciation, or loss of international competitiveness. Hence,

$$
R=P_{N} / e P_{T}^{*}=P_{N} / P_{T}
$$

Changes in this key relative price alter the pattern of production and expenditure in the tradable and non-tradable sectors of the economy, with implications for national income, employment and the current account balance.

In the absence of capital flows, the real exchange rate will adjust to ensure that total spending in the economy equates with total production of tradables and non-tradables, so that the current account is balanced. What follows however significantly extends the original aggregative benchmark approach of Salter (1959) as it provides macrobehavioural and international monetary foundations that make it possible to examine simultaneous variation in the real exchange rate and external imbalance in response to government spending shocks in real exchange rate - tradables, non-tradables space. In particular, it adds conventional monetary, interest parity and balance of payments equilibrium relations. As we will see, it also differs from the well-known Swan (1955) diagram which also stems from Salter's approach. In addition and unlike these previous models, the new framework outlined in what follows allows for reactive foreign lenders, alternative exchange rate regimes, and variation in the degree of capital mobility. 
Total expenditure on tradables and non-tradables, $E_{A}\left(=E_{T}+E_{N}\right)$, is the sum of spending on tradables and non-tradables and takes the form of private consumption and private investment, plus government spending, $G_{T, N}$, assumed to be exogenous. Contrary to the simple Keynesian consumption function, private consumption does not rise proportionately with temporary income variation and so is independent of short run output variation, consistent with the life cycle (Modigliani 1986) and permanent income (Friedman 1957) theories of consumption ${ }^{2}$ as well as more recent intertemporal approaches (see Wickens 2011). Hence, household consumption is responsive to changes in the real exchange rate, permanent income, $\rho$, wealth, $q$, and the domestic interest rate, $r$. Private investment is also a function of the real exchange rate, wealth, $q$, and the domestic interest rate, $r$. National wealth is the market value of the capital stock less foreign liabilities,

$$
q=K_{T}+K_{N}-B^{*}
$$

Hence, for tradables,

$$
\begin{gathered}
E_{T}=f\left(R ; G_{T}, r, \rho, q\right) \\
\partial E_{T} / \partial R>0, \quad \partial E_{T} / \partial G_{T}>0, \quad \partial E_{T} / \partial r<0 \quad \partial E_{T} / \partial \rho>0, \quad \partial E_{T} / \partial q>0
\end{gathered}
$$

whereas for non-tradables,

$$
\begin{aligned}
& E_{N}=f\left(R ; G_{N}, r, \rho, q\right) \\
& \partial E_{N} / \partial R<0, \quad \partial E_{N} / \partial G_{N}>0, \quad \partial E_{N} / \partial r<0, \quad \partial E_{N} / \partial \rho>0, \quad \partial E_{N} / \partial q>0
\end{aligned}
$$

\footnotetext{
${ }^{2}$ Makin and Narayan (2010) and Taylor (2009) provide recent evidence of this for Australia and the United States.
} 
On the production side, it is assumed that the capital stock is fixed in the short run, such that $\bar{K}=\bar{K}_{T}+\bar{K}_{N}$. Within this time frame the available supply of non-tradable and tradable output for sale is a function of the real exchange rate, the change in the level of inventories, $V$, and hours worked by labour, $H$, in both sectors, such that

$$
\begin{gathered}
O_{T, N}=f\left(R ; V_{T, N}, H_{T, N}\right) \\
\partial O_{T} / \partial R<0, \quad \partial O_{N} / \partial R>0, \quad \partial O_{T, N} / \partial V_{T, N}>0, \quad \partial O_{T, N} / \partial H_{T, N}>0
\end{gathered}
$$

\section{Monetary Relations}

The domestic interest rate depends on the money demand - money supply relationship in the standard way. More formally, real money demand, $M_{d}$, is positively related to total spending, $E_{A}$, via parameter $\chi$, and negatively related to the domestic interest rate via parameter $\delta$, such that

$$
M_{d}=\chi E_{A}-\delta r \quad 0<\chi<1 \quad \delta>0
$$

The central bank alters the nominal money supply, $M_{S}$, via changes in its holdings of government bonds, $B_{C}$, and foreign exchange reserves, $\psi$. Hence,

$$
M_{S}=B_{C}+\psi
$$

Under a floating exchange rate, the money supply is invariant, with the nominal exchange rate itself bearing the pressure of external adjustment. Under a fixed nominal exchange rate regime, unsterilized central bank sales (purchases) of foreign exchange decrease (increase) the money supply. Using the equilibrium condition that real money demand equals real money supply,

$$
M_{S}=\chi E_{A}-\delta r
$$

and solving for $r$, 


$$
r=\left(\chi E_{A}-M_{S}\right) / \delta \quad \partial r / \partial E_{A}>0, \quad \partial r / \partial M_{S}<0
$$

This implies increased expenditure on either tradables or non-tradables puts upward pressure on the domestic interest rate due to a rise in money demand relative to a given supply.

\section{The External Accounts and Capital Mobility}

According to interest rate parity, arbitrage ensures the domestic interest rate, $r$, equals the foreign interest rate, $r^{*}$. However, the domestic interest rate can also reflect expected exchange rate depreciation, in accordance with uncovered interest parity, inclusive of a risk premium, $\tau$. This risk premium can be positively related to the stock of government bonds acquired by foreigners, $B^{*}$. Hence,

$$
r=r^{*}+\hat{e}+\tau\left(B^{*}\right) \quad \partial r / \partial B^{*}>0
$$

where $\hat{e}=\frac{f-e}{e}=\frac{f}{e}-1$, with $f$ being the spot exchange rate expected at some time in the future.

Hence, the key monetary influences on the domestic interest rate can be summarised as

$$
r=f\left(M_{d}, M_{s}, r^{*}, \hat{e}, \tau\right)
$$

Next consider the balance of payments, or external accounts. The basic flow equilibrium condition for the external accounts is that the current account balance equals the capital account balance (or equivalently net capital inflow), but with opposite sign. Net capital inflow occurs when an interest differential develops 
between domestic and the given foreign interest rates and continues until interest parity is restored according to relation (12). Hence, external account equilibrium occurs when

$$
C A D\left(R, O_{T, N}, E_{T, N}\right)=K A S\left(r, r^{*}, \hat{e}, \tau\right)
$$

where $C A D$ is the current account deficit and $K A S$ is the capital account surplus, or net capital inflow.

If the budget is initially balanced, an increase in government spending, other things the same, gives rise to a budget deficit funded by the issue of government bonds, $B$. If the current account is also initially balanced, this extra spending generates a current account deficit. Hence foreign investors acquiring these bonds fund both the budget and current account deficits.

With the above standard behavioural relations as foundations, Figure 1, central to the analytics to follow, depicts output-expenditure equilibria in the non-tradable (left panel) and tradable (right panel) sectors of the economy. Note that the two panels share the vertical real exchange rate axis, so that in the left panel non-tradable output is positively related, and non-tradable expenditure negatively related, to the relative price of non-tradables to tradables. In the right panel, the opposite applies, with tradable output negatively related, and tradable expenditure positively related, to $R$. 


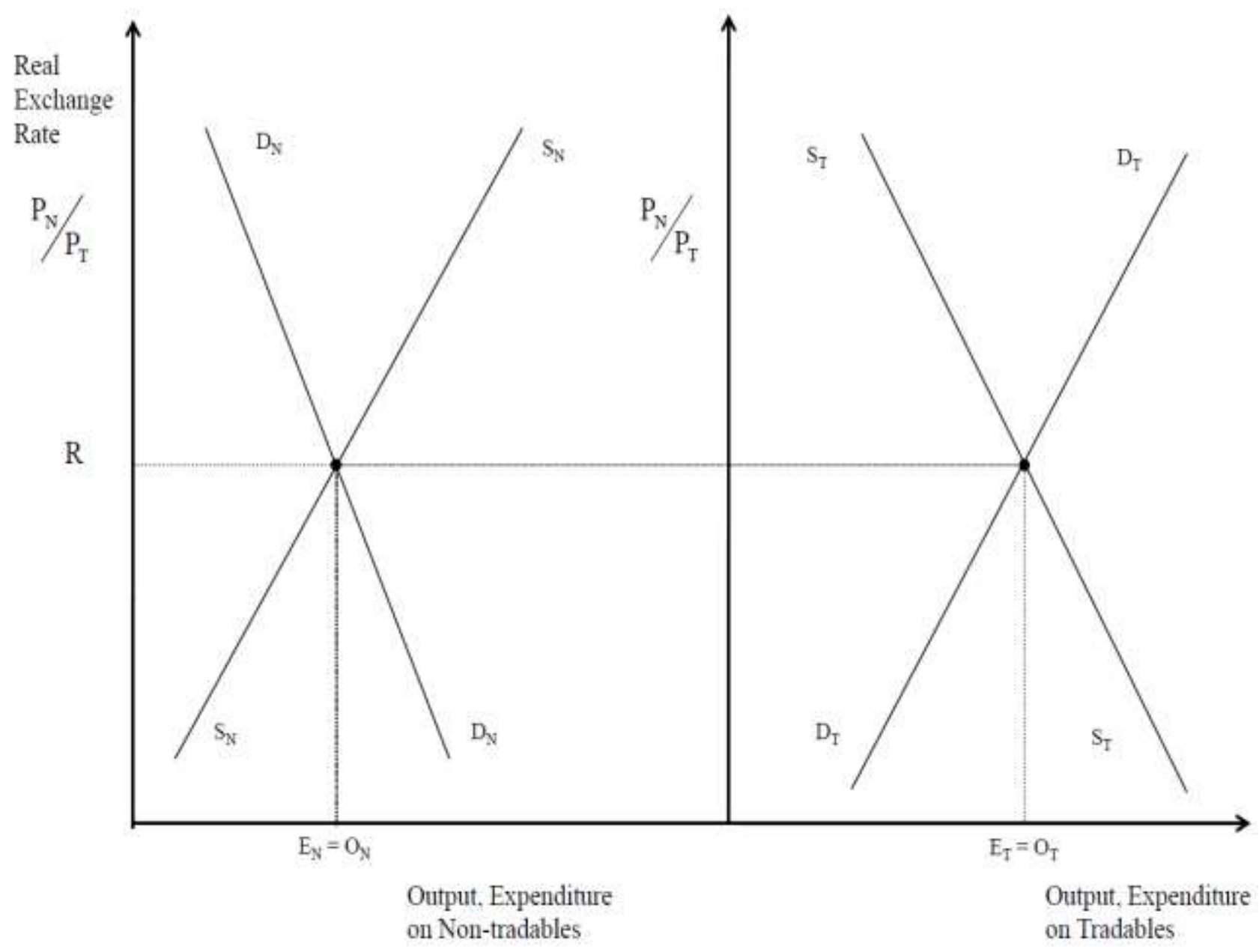

Figure 1 - Equilibrium in Real Exchange Rate - Tradables, Non-tradables Space

In initial equilibrium, aggregate demand equals aggregate output in both the nontradables and tradables sectors. Moreover, it is assumed that the government budget and the current account are in balance at the outset and that interest parity prevails, with no change expected in the nominal exchange rate and no risk premium. With these foundations, it is possible to examine the international macroeconomic effects of an increase in government spending under floating and fixed nominal exchange rates. 


\section{Increased Government Spending}

Increased government spending may conceivably be on either tradables or nontradables. Although in practice public spending on non-tradables is the norm, it is of interest to compare the different international macroeconomic effects of each kind of spending. First consider increased spending on tradables, then on non-tradables.

\section{Higher Spending on Tradables}

A rise in public spending on tradables shifts the tradables demand schedule out, as shown in the right panel of Figure 2, giving rise to budget and current account deficits funded via foreign lenders' bond purchases recorded in the matching capital account of the balance of payments accounts. This capital inflow is induced by the tendency for the domestic interest rate to rise above the world rate as money demand rises to satisfy increased transactions demand stemming from the additional expenditure. However, the domestic interest rate is ultimately anchored to the foreign rate via the interest parity relationship.

As capital inflow provides an increased supply of foreign exchange to match the increased demand arising from the $C A D$, the nominal exchange rate remains stable. Hence as the extra spending on tradables is reflected in the $C A D$ with no impact on $P_{T}$, the real exchange rate is also invariant and so has no competitiveness effect on production or employment in either the tradable or non-tradable sectors. In other words, although total spending initially rises following fiscal stimulus, neither domestic tradable output, $O_{T}$, nor non-tradable output, $O_{N}$, increases. 
Since a rise in total output is a necessary condition for increasing overall employment, fiscal stimulus in the form of increased public spending on tradables is ineffective in the short run. The $C A D$ that arises from the extra government spending, as shown in the left panel of Figure 3, persists as long as foreign bondholders expect no change in the nominal exchange rate and no significant interest risk premium or wealth effects emerge as external indebtedness rises.

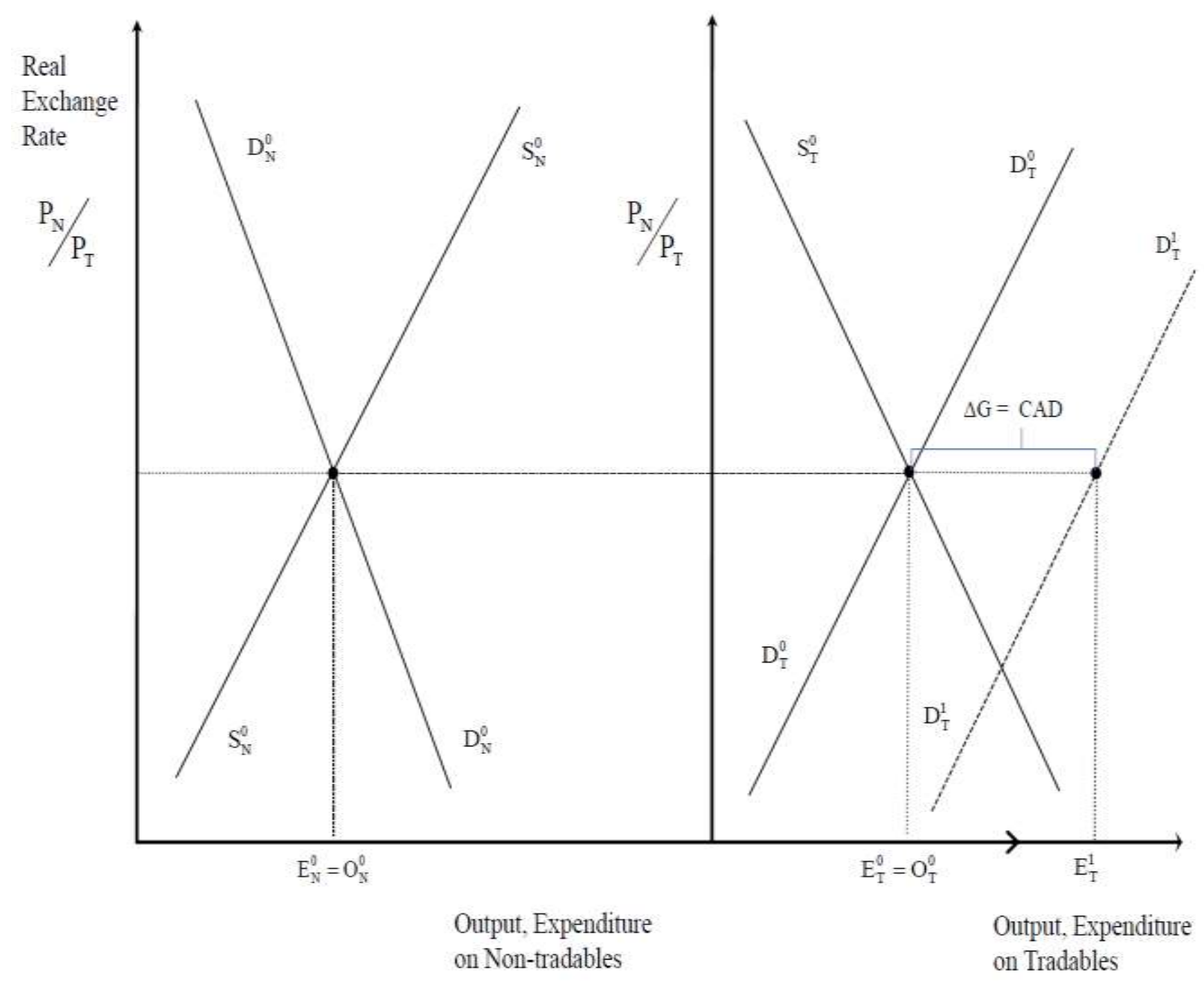

Figure 2 Increased Public Spending on Tradables 
Interestingly, if the nominal exchange rate was officially fixed and international capital was free to move unrestricted, this ineffectiveness result still holds to the extent the supply of foreign exchange matches the increased demand arising from the $C A D$. This assumes there is no risk premium or wealth effect, as above for the pure floating rate case with high capital mobility, although this assumption is subsequently relaxed.

\section{Higher Spending on Non-Tradables}

Now consider how the effects differ if the increased public spending is on nontradables, the usual case, since government spending is predominantly focused on non-tradable activities. ${ }^{3} \quad$ As shown in Figure 4 increased public spending on nontradables shifts the $D_{N} D_{N}$ schedule rightward in the left panel, creating an excess demand for non-tradables, putting upward pressure on $P_{N}$. As total expenditure increases, the concomitant rise in the demand for money, for a given money supply, tends to raise the domestic interest rate above the world interest rate. Hence, the resultant capital inflow funds the $C A D$ attributable to the real exchange rate appreciation, as depicted in Figure 4.

Meanwhile, this real exchange rate appreciation increases the output of non-tradables, as working hours are extended and inventories are run down in that sector, while tradable output decreases due to a loss of competitiveness as an offset. Real exchange rate appreciation, defined in this approach as a rise in the relative price of nontradables to tradables, is consistent with the real exchange rate appreciation predicted

\footnotetext{
${ }^{3}$ Morshed and Turnovsky (2004) have suggested the non-tradable share of government is up to 90 per cent.
} 
in the fiscal transmission mechanism of the Mundell-Fleming and other models. ${ }^{4}$ In this model whether overall national output and hence employment stays the same, rises, or falls in the short term, remains ambiguous. It ultimately depends on whether the elasticity of tradable output differs from the elasticity of non-tradable output with respect to the real exchange rate. ${ }^{5}$

Interestingly, if the central bank pegged the nominal exchange rate under conditions of high capital mobility, the real exchange rate would still appreciate as the price of non-tradables, $P_{N}$, rises due to the extra government spending on non-tradables. Moreover, the central bank would not need to intervene to influence the value of the nominal exchange rate, provided its pegged value reflects the initial fundamentals and the higher incipient interest rate induces capital inflow to match the $C A D$. Hence, under these assumptions, and contrary to the Mundell-Fleming approach, the nature of the exchange rate regime has little bearing on the effects of fiscal stimulus in the form of higher spending on national output and hence employment. ${ }^{6}$

\footnotetext{
${ }^{4}$ See for instance Frenkel and Razin (1992) and Cogan, Taylor, Wieland and Wolters (2013). On the contrary, Monacelli and Perotti (2010) provide VAR evidence of a depreciation response to increased government spending.

5 The prediction that increased government spending disproportionately benefits the non-tradable sector and widens the external deficit is consistent with empirical work by Benetrix and Lane (2010).

6 This contrasts with VAR evidence provided in Born, Juessen and Muller (2013).
} 


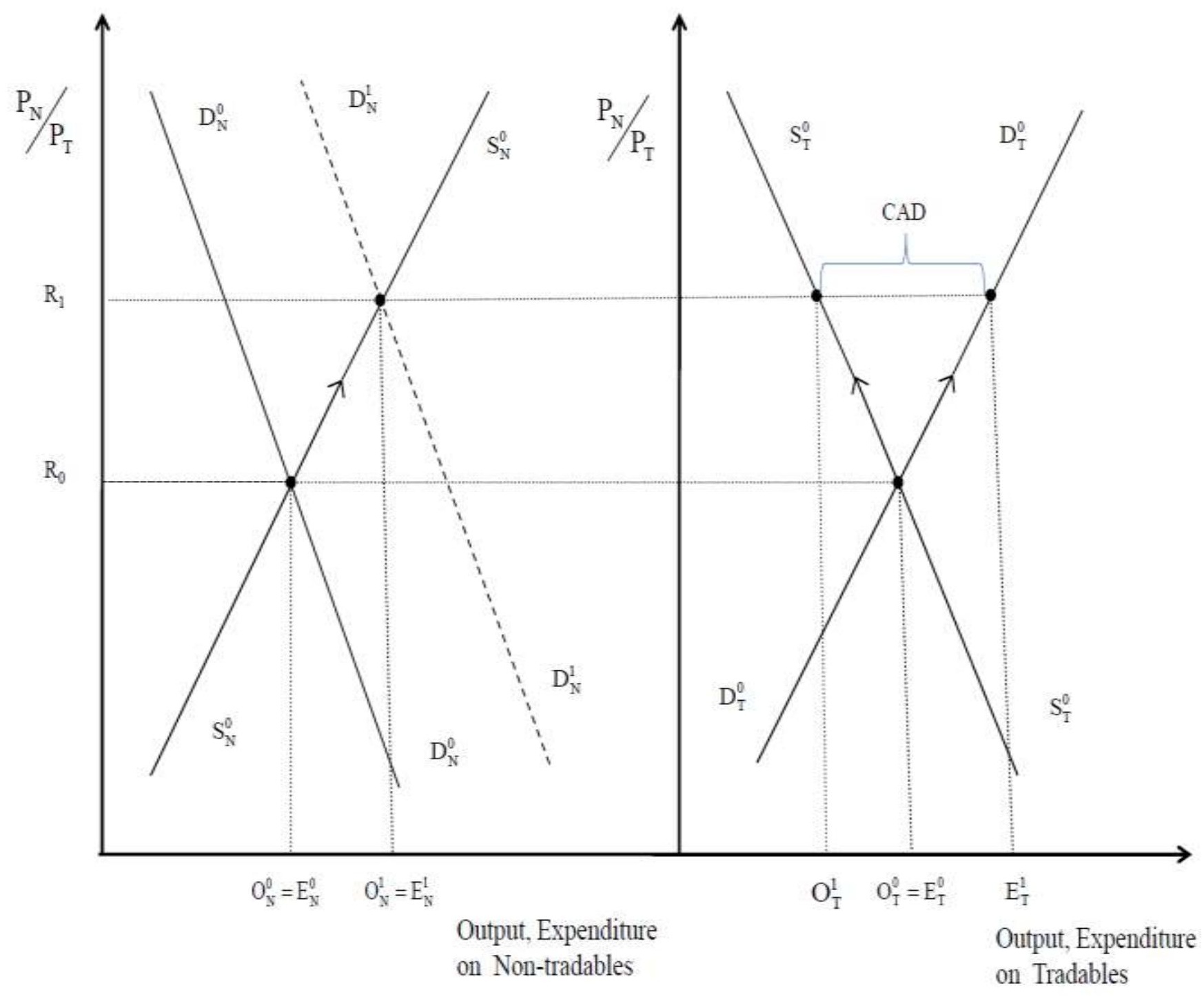

Figure 3 - Increased Public Spending on Non-tradables

Importantly, even though the extra government spending originated in the nontradable sector, the framework reveals that it creates a $C A D$, just as if the increased spending had been on tradables. This is consistent with the CAD reflecting a reduction in total saving relative to total investment across both sectors. That is $\Delta C A<0=\left(I_{T}+I_{N}\right)-\left(Y-\left(C_{T}+C_{N}+\Delta G\right)\right)=I-\Delta S$ 


\section{Unsustainable Current Account Deficits and Fixed Exchange Rates}

It is now possible to explore the implications of reactive foreign lenders who may deem any incipient $\mathrm{CAD}$ arising from the extra government spending to be unsustainable, as well as the fixed nominal exchange rate case with capital immobility.

\section{Unsustainable Current Account Deficits}

If the $C A D$ is deemed unsustainable by foreign lenders, the nominal exchange rate would be expected to depreciate. The domestic interest rate would then rise above the world rate via the interest parity relation, more so if a significant risk premium also emerges due to the rise in public external debt. This higher domestic interest rate then reduces spending on both tradables and non-tradables, shown by the leftward shift in both demand schedules in Figure 4.

Whether there is a net increase or decrease in total output, and hence employment, after real exchange rate adjustment is again ambiguous a priori. It would be zero if the fall in tradable output fully offsets any net rise in non-tradable output, or slightly positive or negative, depending on how the elasticities of output with respect to the real exchange rate differ for each sector. 


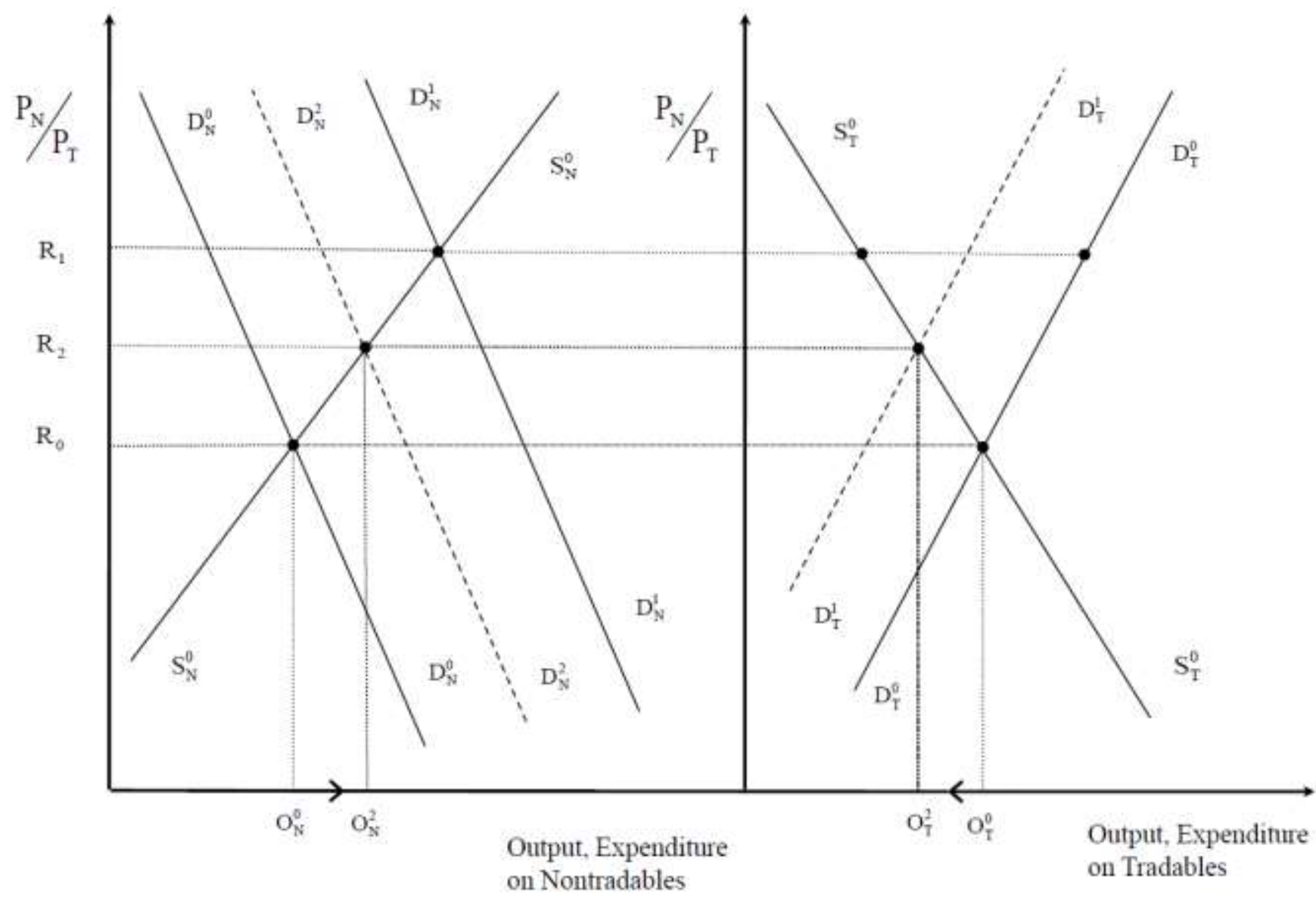

Figure 4 - Unsustainable Public Spending

\section{Government Spending Under Fixed Exchange Rates with Capital Immobility}

Figure 4 also conveys adjustment when the nominal exchange rate is fixed and capital controls prohibit capital inflow. Even if the nominal exchange rate is pegged, the real exchange rate appreciates via a rise in $P_{N}$ following increased public spending on non-tradables. The $C A D$ that results from this real exchange rate appreciation then has to be funded by the central bank running down its foreign exchange reserves. This would contract the money supply, raise the domestic interest rate, and thereby reduce spending on both tradables and non-tradables. In the transition to the final short term real exchange rate equilibrium, the net rise in non-tradable output is offset 
by a fall in tradable output. Under a fixed nominal exchange rate, fiscal stimulus therefore again proves ineffective as a stabilisation tool.

\section{Ricardian Effects}

Another reason the expenditure schedules could shift leftward under either floating or fixed exchange rates is that national wealth falls as external debt rises in accordance with earlier relation (4). Households, mindful of the future income taxes necessary to repay foreign debt incurred due to additional government spending, save rather than consume, as proposed by the Ricardian equivalence proposition (Barro 1974, Bernheim 1987, Seater 1993, Ricciuti 2003). ${ }^{7}$ Firms also invest less as wealth falls. If higher public spending negates consumption and investment spending in this way, the tradable and non-tradable demand schedules would shift leftward in response to the budget deficit increase. The above analysis has treated government spending as consumption in nature, rather than investment. In the case of increased public investment, the stock of capital would rise, offsetting the negative wealth effect of the rise in public debt.

\section{Concluding Comments}

This paper has addressed a topic of major importance to contemporary macroeconomic policy by re-examining the international macroeconomic effects of increased government spending within a two sector open economy framework based on the classic distinction between tradables and non-tradables. By providing new international monetary underpinnings and combining this goods and services markets specification with the distinction between national income and expenditure, this

\footnotetext{
${ }^{7}$ The most comprehensive study to date of the public-private saving offset by Loayaza, SchmidtHebbel and Serven (2000) using World Bank data for 150 countries found this offset close to 0.7.
} 
framework yields a graphically different transmission mechanism for government spending under alternative exchange rate regimes.

The fiscal policy transmission mechanism of the model is as follows. Increased public spending on tradables, creates a $C A D$ matched by capital inflow, induced by an incipiently higher domestic interest rate due to increased money demand. With capital mobility and no adverse reactive behaviour by foreign investors, the budget and current account deficits tend to be twinned under these conditions consistent with Makin (2004). Since the real exchange rate and hence competitiveness is unaffected, irrespective of the exchange rate regime, overall output remains unchanged. Hence increased government spending on tradables is ineffective in influencing national output.

On the other hand, increased public spending on non-tradables, the normal case, increases the price of non-tradables relative to tradables. This worsens the competitiveness of the tradable sector, reducing the production of tradables while increasing tradables expenditure. Higher money demand puts upward pressure on domestic interest rates which induces the capital inflow required to fund the resultant $C A D$. Hence, increased public spending on non-tradables has an ambiguous in principle effect on total output and employment. Critically however, the actual sign and size of government spending multipliers for any country would depend on the relative strengths of estimable output elasticities for tradables and non-tradables with respect to the real exchange rate. 
The main results of this alternative approach are summarised in Table 1. In sum, the framework yields the following novel results. First, although government spending on either tradables or non-tradables always enlarges the current account deficit, in the former and less applicable case, this does not affect the real exchange rate, whereas in the latter case, it causes real exchange rate appreciation. Second, irrespective of the sector in which the government spending occurs, the short run boost to overall output and employment seems insignificant a priori. However, in reality this would depend on the output elasticities of each sector with respect to the real exchange rate.

\section{Table 1 Macroeconomic Effects of Increased Government Spending}

Impact of Rise in $G$ on:

Tradables

BD $\quad \mathrm{R} \quad \mathrm{CAD}$ GDP

Floating exchange rate, capital mobility

Fixed exchange rate, capital mobility

Fixed exchange rate, capital immobility

$\begin{array}{cccc}\uparrow & 0 & \uparrow & 0 ? \\ \uparrow & 0 & \uparrow & 0 ? \\ \uparrow & \downarrow & 0 & 0 ?\end{array}$

Non-tradables

Floating exchange rate, capital mobility

Fixed exchange rate, capital mobility

Fixed exchange rate, capital immobility

$\begin{array}{cccc}\uparrow & \uparrow & \uparrow & 0 ? \\ \uparrow & \uparrow & \uparrow & 0 ? \\ \uparrow & \uparrow & 0 & 0 ?\end{array}$

By showing how government spending influences the real exchange rate, defined as the relative price of non-tradables to tradables, these results provide an alternative perspective to basic Mundell-Fleming analysis. Moreover, under conditions of restricted capital mobility and pegged exchange rates, fiscal stimulus remains 
ineffective. Consequently, the results under either form of exchange rate regime are highly relevant to ongoing debate about the effectiveness of fiscal policy. In suggesting that short run government spending may have little impact on national output, these results also contrast sharply with those of basic closed economy Keynesian theory and numerous recent empirical studies that stem from its assumptions.

\section{References}

Alexander, S. (1952) "Effects of a Devaluation on a Trade Balance", IMF Staff Papers, 2, 263-78.

Asea, P. and Mendoza, E. (1994) "The Belassa-Samuelson Model: A General Equilibrium Appraisal” Review of International Economics, 2, 244-267.

Auerbach, A., Gale, W. and Harris, B. (2010) "Activist Fiscal Policy" Journal of Economic Perspectives 24 (4), 141-164.

Barro, R. (1974) “Are Government Bonds Net Wealth?” Journal of Political Economy, 81, 1095-1117.

Beetsma, R., Guiliodori, M. and F. Klaassen (2008) "The Effects of Public Spending Shocks on Trade Balances and Budget Deficits in the Europeam Union" Journal of the European Economic Association 6 (2-3), 414-423.

Benetrix, A., and Lane, P. (2010) "Fiscal Shocks and the Sectoral Composition of Output” Open Economies Review 21(3), 335-350.

Bernheim, D. (1987) "Ricardian Equivalence: An Evaluation of Theory and Evidence" in S. Fischer (ed.) NBER Macroeconomics Annual 1987, Cambridge, MIT Press, Massachusetts.

Born, B., Juessen, F. and G. Muller (2013) "Exchange Rate Regimes and Fiscal Multipliers" Journal of Economic Dynamics and Control 37, 446-465.

Born, B. and Muller. G. (2012) "Government Spending in Quarterly and Annual Time Series" Journal of Money, Credit and Banking, 117(4), 1329-1368.

Cardi, O. and Muller, G. (2011) "Habit Formation and Fiscal Transmission in Open Economies" Journal of International Economics 85, 256-267. 
Cardi, O. and Restout, R. (2012) "Fiscal Shocks in a Two Sector Open Economy With Endogenous Markups" Working Paper of BETA 2012-17.

Cogan, J., Taylor, J., Wieland, V. and Wolters, M. (2013) Journal of Economic Dynamics and Control, (37), 404-421.

Cogan, J. Cwik T., Taylor J., and Wieland, V. (2010) 'New Keynesian versus Old Keynesian Multipliers', Journal of Economic Dynamics and Control, 34(3), 281-295.

Corsetti, G. and Muller, G. (2006) "Twin Deficits: Squaring Theory, Evidence and Common Sense" Economic Policy, 48, 597-638.

Corsetti, G., Meier, A. and Muller, G. (2012) "What Determines Government Spending Multipliers?" Economic Policy, forthcoming.

Cortuk, O. (2013) "A Disaggregated Approach to the Determination of Government Spending Multipliers” Journal of Economic Policy Reform 16(1), 31-45.

Coto-Martinez, J. and Dixon, H. (2003) "Profits, Markups and Entry: Fiscal Policy in an Open Economy" Journal of Economic Dynamics and Control 27(4), 573-597.

Davig, T. and Leeper,E. (2011) "Monetary - Fiscal Interactions and Fiscal Stimulus" European Economic Review 55, 211-227.

Dornbusch, R. (1975) 'Exchange Rates and Fiscal Policy in a Popular Model of International Trade" American Economic Review 65, 859-71.

Fischer, S. and Frenkel, J. (1972) "Investment in a Two Sector Model and Trade in Debt and Capital Goods" Journal of International Economics 2, 211-233.

Fleming, J. (1962), "Domestic Financial Policies Under Fixed and Under Floating Exchange Rates", IMF Staff Papers, 12, 369-80.

Frenkel J. and Razin, A. (1992) Fiscal Policies and the World Economy, Cambridge: MIT Press.

Friedman, M. (1957) A Theory of the Consumption Function, Princeton University Press, New Jersey.

Gali, J. Lopez-Salido D and Valles, J. (2007) "Understanding the Effects of Government Spending on Consumption" Journal of the European Economic Association 38, 1, 117-32.

International Monetary Fund (2010) World Economic Outlook, Chapter 3, International Monetary Fund, Washington.

Kollmann, R. (2010) "Government Purchases and the Real Exchange Rate" Open Economies Review 21, 49-64. 
Loayza, N. Schmidt-Hebbel, K. and Serva, L. (2000) "What Drives Private Saving Across the World?" Review of Economics and Statistics 82, 165-181.

Makin, A. (2013) "Commodity Prices and the Macroeconomy: An Extended Dependent Economy Approach” Journal of Asian Economics 24, 80-88.

Makin, A. (2004) "The Current Account, Fiscal Policy and Medium Run Income Determination” Contemporary Economic Policy (22), 309-317.

Makin, A. and Narayan, P. (2011) "How Potent is Fiscal Policy in Australia?" Economic Papers 30(3), 377-385.

Modigliani, F. (1986) "Life Cycle, Individual Thrift, and the Wealth of Nations" American Economic Review 76, June, 297-313.

Monacelli, T. and Perotti, R. (2010) "Fiscal Policy, the Real Exchange Rate and Traded Goods" Economic Journal, 120, 437-461.

Morshed, M. and Turnovsky, S. (2004) "Sectoral Adjustment Costs and Real Exchange Rate Dynamics in a Two Sector Dependent Economy" Journal of International Economics 63, 147-177.

Mountford, A. and Uhlig, H. (2009) 'What Are the Effects of Fiscal Policy Shocks?', Journal of Applied Econometrics, 24(6), 960-992.

Mundell, R. (1963), "Capital Mobility and Stabilization Policy Under Fixed and Flexible Exchange Rates", Canadian Journal of Economics and Political Science, 29, 475-85.

Obstfeld, M. and Rogoff, K. Foundations of International Macroeconomics, MIT Press, Boston, 1996.

Ramey, V. (2011) "Identifying Government Spending Shocks: It's All in the Timing" Quarterly Journal of Economics 126(1), 1-50.

Ravn, M., Schmitt-Grohe, S. and Uribe, M. (2012) "Consumption, Government Spending and the Real Exchange Rate" Journal of Monetary Economics 59, 215-234.

Ricciutti, R "Assessing Ricardian Equivalence" Journal of Economic Surveys (17, 1, 2003).

Romer, C. and Romer, D. (2010) 'Effects of Tax Changes: Estimates Based on a New Measure of Fiscal Shocks', American Economic Review, 100, 763-801.

Salter, W. (1959) "Internal and External Balance: The Role of Price and Expenditure Effects" Economic Record 35, 226-238.

Sarno, L. and Taylor, M. (2003) The Economics of Exchange Rates Cambridge University Press, Cambridge. 
Seater, J. (1993) “Ricardian Equivalence” Journal of Economic Literature, 31(1), 142-90.

Swan, T. (1955) "Longer Run Problems of the Balance of Payments" reprinted in Caves, R. and Johnson, H. (eds) (1968) Readings in International Economics, Irwin, New York.

Swan, T. (1960) "Economic Control in a Dependent Economy" Economic Record, $36,51-66$.

Tagkalakis, A. (2008) "The Effects of Fiscal Policy on Consumption in Recessions and Expansions" Journal of Public Economics 92, 1486-1508.

Taylor, J. (2009) “The Lack of an Empirical Rationale for a Revival of Discretionary Fiscal Policy" American Economic Review, Papers and Proceedings, 99, 2.

Turnovsky, S. and Sen, P. (1995) "Investment in a Two Sector Dependent Economy" Journal of the Japanese and International Economies 9, 29-55.

Wickens, M. (2011) Macroeconomic Theory: A Dynamic General Equilibrium Approach, Princeton University Press, Princeton.

Woodford, M. (2011) "Simple Analytics of the Government Expenditure Multiplier" American Economic Journal: Macroeconomics 3, 1-35.

Yano, M. and Nugent, J. (1999) “Aid, Non-Traded Goods and the Transfer Paradox in Small Countries” American Economic Review 89, 431-449. 